\title{
CENTRAL CORNEAL THICKNESS, CORNEAL CURVATURE AND REFRACTIVE ERROR IN PATIENTS WITH PRIMARY ANGLE-CLOSURE GLAUCOMA AND PRIMARY OPEN-ANGLE GLAUCOMA
}

\section{AUTHORS}

Marić V. ${ }^{1}$, Marković V. ${ }^{1,2}$, Božić M. ${ }^{1,2}$, Marjanović I. ${ }^{1,2}$

${ }^{1}$ Clinic for Eye Diseases, Clinical Center of Serbia, Belgrade, Serbia

${ }^{2}$ University of Belgrade, School of Medicine, Belgrade, Serbia
CORRESPONDENT

VESNA MARIĆ

Clinic for Eye Diseases, Clinical Center of Serbia, Belgrade, Serbia

$\triangle$ vesbabic@sezampro.rs

\section{SUMMARY}

Primary angle-closure glaucoma (PACG) is highly prevalent in Asian countries, compared with primary open-angle glaucoma (POAG), which is reported predominant disease among Whites and that is the reason for paucity of reports about central corneal thickness (CCT) and corneal curvature (CC) in eyes with PACG in Europe. To determine central corneal thickness, corneal curvature and refractive error in patients with primary angle-closure glaucoma (PACG) and primary open-angle glaucoma (POAG). A total of 288 patients were enrolled into this study; 132 patients with PACG (mean age of $73 \pm 7$ years) compared with 156 patients with POAG (mean age of $70 \pm 7$ years). The data was collected from all PACG patients who underwent Laser peripheral iridotomy at the Clinic for Eye Diseases, Clinical Center of Serbia in Belgrade between January 2012 and October 2012 and controls with POAG examined in the same period. Data from the right eye was used for analysis. In PACG/POAG mean CCT was $549 \pm 38 / 547 \pm 35 \mu \mathrm{m}(\mathrm{p}=0.353)$ and mean radius of corneal curvature $(\mathrm{Cr})$ was $7.92 \pm 0.22 / 7.75 \pm 0.29 \mathrm{~mm}(\mathrm{p}=0.003)$. There was no statistically significant correlation between IOP and mean $\mathrm{Cr}$ in PACG $(\mathrm{p}=0.244)$ and POAG $(\mathrm{p}=0.637)$ while it was in POAG group with refractive error $(p=0.005)$ and CCT $(p<0.001)$. We found that CCT in PACG and POAG group were in normal range and there was no diference between them. Our results showed that the eyes with PACG had the flatter corneas than eyes with POAG and were hyperopic.

Keywords: central corneal thickness, corneal curvature, refractive error, primary angle-closure glaucoma, primary open-angle glaucoma

\section{INTRODUCTION}

Primary angle-closure glaucoma (PACG) is highly prevalent in Asian countries, compared with primary open-angle glaucoma (POAG), which is reported predominant disease among Whites [1]. The prevalence of PACG in Europe is $0.1 \%$ [2]. However, the Egna -Neumarkt Glaucoma Study stated that the burden of PACG in Europe has been underestimated previously [3]. Laser peripheral iridotomy (LPI) is considered the first choice treatment for PACG although advanced cases require further treatment with topical medication or filtration surgery [4].

The role of central corneal thickness (CCT) measerment in clinical evaluation in glaucoma is established [5]. Earlier studies have identified that CCT has significant effect on intraocular pressure (IOP) values measured with Goldmann applanation tonometry (GAT); true IOP in eyes with thicker corneas is lower than that is measured and thinner corneas lead to lower readings. Besides CCT, the accuracy of GAT depends on many other factors including corneal curvature, corneal structure and axial length [6]. Corneal curvature $(\mathrm{CC})$ is another factor affecting $I O P$ and $C C T$ readings.

The aim of this study is to investigate CCT, corneal curvature and refractive error in patients with PACG and compare data with the same data in POAG patients. However, there is paucity of reports about CCT and CC in eyes with PACG in Europe, because most researches have been done in parts of Asia where the anatomy of the eyes might be different from eyes in Europeans and myopia is more prevalent than in Europe [7].

\section{THE AIM}

To determine central corneal thickness, corneal curvature and refractive error in patients with primary angle-closure glaucoma and primary open-angle glaucoma.

\section{MATERIAL AND METHODS}

A total of 288 patients (288 eyes) were enrolled into this cross-sectional study; 132 patients (132 eyes) with 
PACG (mean age of $73 \pm 7$ years) compared with 156 patients (156 eyes) with POAG (mean age of $70 \pm 7$ years). The data was collected from all PACG patients who underwent LPI at the Clinic for Eye Diseases, Clinical Center of Serbia in Belgrade between January 2012 and October 2012 and controls with POAG examined in the same period. Patients consistent with the diagnoses of POAG and PACG who were referring to the Clinic for Eye Diseases for LPI were included in the study.

Exclusion criteria were: (1) secondary glaucoma; (2) corneal abnormalities that prevented accurate CCT measurement; (3) previous intraocular surgery; (4) previous trauma; (5) other nonglaucomatous neuropathies and (6) narrow angles without physical or functional signs of glaucoma. Beside data about demographic characteristics, all patients underwent a complete ophthalmic examination by a glaucoma specialist including visual acuity (Snellen chart), slitlamp biomicroscopy, gonioscopy, IOP measurement with Goldmann applanation tonometry and fundus examination using indirect ophthalmoscopy with Volk Superfield lens 90D. Diagnostic observation also included a visual field test using the Threshold C 24-2 Swedish Interactive Testing Algorithm (SITA) standard program with Humphrey visual field analyzer II (Carl Zeiss, Germany) and scanning laser ophthalmoscopy - Heidelberg retinal tomography (HRT II, Heidelberg Engineering, $\mathrm{GmbH}$, Dossenheim, Germany, version 2.02). CCT values were measured by ultrasonic pachymeter (Alcon laboratories, OcuScan $\otimes R x P$ Ophthalmic Ultrasound system, Fort Wortx TX) by trained ophthalmic technicians. The pachymetry measurement recorded for each eye was the average of 3 measurements taken per eye. Corneal curvature and refractive error was measured with autokeratorefractometer (Topcon KR-7000). Corneal curvature measurements were expressed as radius of corneal curvature $(\mathrm{Cr})$ and keratometry values $(\mathrm{K})$. Refractive error was calculated as spherical equivalent in diopters (D), as the sum of the sphere and half the refractive astigmatism.

\section{DEFINITIONS OF GLAUCOMA}

Glaucoma was defined as the presence of glaucomatous optic neuropathy (GON) - (defined as loss of neuroretinal rim with a vertical cup: disc ratio of $>0.7$ or an inter-eye asymmetry of $>0.2$, and/ or notching attributable to glaucoma) and associated visual field loss. PACG was defined as the presence of GON with corresponding visual field loss, in association with a closed angle (presence of at least 180 degrees of angle in which the posterior trabecular meshwork was not visible on nonindentation gonioscopy), and raised IOP and/or peripheral anterior synechiae. There were no cases of acute angle closure and all PACG patients had chronic PACG. POAG was defined as GON, visual field defects consistent with glaucoma, IOP greater than $21 \mathrm{~mm} \mathrm{Hg}$ on at least 2 occasions, and open angles on gonioscopy.

All patients received a detailed explanation about the study and signed informed consent for use of their data for the analysis.

This study was approved by the Ethics Committee of the Clinical Center of Serbia within which the work was undertaken.

\section{STATISTICAL ANALYSIS}

Data from the right eye was used for analysis. If the right eye was excluded from the study because of ineligibility, data from the left eye was used. Standard descriptive statistics were used. Unpaired Student's t-test was used for comparison of the continuous variables. Chisquare or Fisher's exact tests were used to evaluate the significance of the differences between categorized data. Correlation between parameters was tested by using Pearson and Spirman correlation and multivariant linear regression model. Individual differences were considered to be statistically significant for $p<0.05$. SPSS version 21.0 (SPSS Inc, Chicago, IIl) was used for all statistical calculations.

\section{RESULTS}

Demographic data and intraocular pressure of the patients are given in Table 1 . The mean patients age in group PACG was $73 \pm 7$ years (range 61-87 years) and they were predominantly female $(75 \%)$ and in group with POAG the mean age was $70 \pm 7$ years (range $58-80$ years) and they were predominantely male $(52 \%)$. There were statistically significant difference between PACG and POAG group regarding to sex and no difference regard to $I O P$, in group with PACG, IOP was $17 \pm 3 \mathrm{mmHg}$ (range 10 $25 \mathrm{mmHg}$ ) and in group POAG was $18 \pm 4 \mathrm{mmHg}$ ( range $12-30 \mathrm{mmHg}$ ).

Mean CCT, CC and refracive error values in both group are given in Table 2. The mean (SD) CCT in PACG group was $549 \pm 38 \mu \mathrm{m}$ (range 509-601 $\mu \mathrm{m})$ and in POAG group was $547 \pm 35 \mu \mathrm{m}$ (range 453-601 $\mu \mathrm{m}$ ). There was no difference between the mean CCT in both groups. Eyes with PACG had flatter corneas, mean $\mathrm{Cr} / \mathrm{K}$ in PACG group were $7.92 \pm 0.22 \mathrm{~mm}$ (range 7.47-8.46 mm) / 42.62 \pm 1.7 D ( range 39.87-45.19 D) and in POAG group were $7.75 \pm 0.29 \mathrm{~mm}$ (range 6.96-8.20 mm) / 43.50 $\pm 1.65 \mathrm{D}$ (range 41.12-48.42D) $(\mathrm{p}=0.003 / \mathrm{p}=0.006)$.

Patients in PACG group were predominantly hyperopic, spherical equivalent ranged between -1.00 do +6.25 diopter, mean value was +2.75 diopter and in POAG group were predominantly myopic, spherical equivalent ranged between -5.25 do +2.00 , mean value was -1.75 diopter.

The IOP positively correlated with CCT $(r=0.772$, $p<0.001)$, refracive error $(r=0.544, p=0.005)$ and age $(r=0.532, p=0.035)$ in group POAG and did not correlate with $\mathrm{Cr}(\mathrm{r}=0.10 \mathrm{p}=0.637)$ and sex $(\mathrm{r}=0.230, \mathrm{p}=0.109)$ in the same group. In group PACG , IOP did not correlate with all variables: CCT $(r=0.405, p=0.06), \mathrm{Cr} \quad(r=0.248$, $p=0.244)$, refractive error $(r=-0.035,0.869)$, age $(r=0.234, p=0.083)$ and sex $(r=0.148, p=0.273)$ (Table 3$)$. In multiple regresion analysis, with IOP as dependent parameter and CCT, CC, refractive error, age and sex as independent parameteres, we found the association between IOP and refractive error $(p=0.001)$ and age $(p=0.039)$ in group POAG and did not reveal the association between IOP and variables in group PACG. We can predict IOP in POAG group on the basis of these two predictors and mathematical model was $1 O P=2.058$ + 1.923xSE + 0.245xAge.

In both group (PACG/POAG) there was no correlation between CCT and variables: $\mathrm{Cr}(\mathrm{p}=0.430 / 0.92)$, re- 
Table 1. Demographic characteristics and IOP in PACG and POAG group

\begin{tabular}{|c|c|c|c|}
\hline Variables & PACG & POAG & $\mathrm{p}$ \\
\hline Age (y) (range) & $73 \pm 7(61-87)$ & $70 \pm 7(58-80)$ & 0.279 \\
\hline Male/female (\%) & $33(25) / 99(75)$ & $81(52) / 75(48)$ & 0.042 \\
\hline IOP (mmHg) (range) & $17 \pm 3(10-25)$ & $18 \pm 4(12-30)$ & $0.6 \overline{4} \overline{7}^{-}$ \\
\hline
\end{tabular}

Abbreviation: IOP - intraocular pressure; PACG - primary angle-closure glaucoma; POAG - primary open-angle glaucoma; y years

Table 2. CCT, CC and refractive error in PACG and POAG group

\begin{tabular}{|c|c|c|c|}
\hline Variables & PACG & POAG & $\mathrm{p}$ \\
\hline CCT $(\mu \mathrm{m})$ & $549 \pm 38(509-601)$ & $547 \pm 35(453-601)$ & 0.353 \\
\hline $\mathrm{Cr}(\mathrm{mm})$ & $7.92 \pm 0.22(7.47-8.46)$ & $7.75 \pm 0.29(6.96-8.20)$ & 0.003 \\
\hline $\mathrm{K}(\mathrm{D})$ & $42.62 \pm 1.7(39.87-45.19)$ & $43.50 \pm 1.65(41.12-48.42)$ & 0.006 \\
\hline $\bar{S} \bar{E}(\mathrm{D})$ & $+2.75(-1.00 \mathrm{do}+6.25)$ & $-1.75(-5.25 \mathrm{do}+2.00)$ & $<0.001$ \\
\hline
\end{tabular}

Abbreviation: CCT - central corneal thickness; $\mathrm{Cr}$ - radius of corneal curvature (mm), $\mathrm{K}$ - keratometry (D); SE - spherical equivalent; D - Diopter

Table 3. Correlation between IOP and variables

\begin{tabular}{|c|c|c|c|c|}
\hline \multirow{2}{*}{ Variables } & PACG & \multicolumn{3}{|c|}{ POAG } \\
\hline & $r$ & $p$ & $r$ & $p$ \\
\hline CCT & 0.405 & 0.06 & 0.772 & $<0.001$ \\
\hline $\mathrm{Cr}(\mathrm{mm})$ & 0.248 & 0.244 & 0.10 & 0.637 \\
\hline $\mathrm{K}(\mathrm{D})$ & 0.283 & $0.181^{\circ}$ & 0.072 & 0.733 \\
\hline $\bar{S} \bar{E}^{-}(\mathrm{D})$ & $-0.0 \overline{3} \overline{5}^{-}$ & $0.869^{-}$ & $0.5 \overline{4} 4$ & 0.005 \\
\hline Agge $(y)$ & 0.234 & $0.083^{-}$ & 0.532 & 0.035 \\
\hline Sex & 0.148 & 0.273 & 0.230 & 0.109 \\
\hline
\end{tabular}

Abbreviation: CCT - central corneal thickness; $\mathrm{Cr}$ - radius of corneal curvature (mm), K - keratometry (D); SE - spherical equivalent; D - Diopter

Table 4. Correlation between CCT and variables

\begin{tabular}{|c|c|c|c|c|}
\hline \multirow{2}{*}{ Variables } & PACG & \multicolumn{3}{|c|}{ POAG } \\
\hline & $r$ & $p$ & $r$ & $p$ \\
\hline $\mathrm{Cr}(\mathrm{mm})$ & 0.169 & 0.430 & 0.02 & 0.92 \\
\hline $\mathrm{K}(\mathrm{D})$ & -0.105 & 0.618 & -0.244 & 0.250 \\
\hline $\bar{S} \bar{E}(D)$ & -0.270 & 0.191 & -0.108 & 0.615 \\
\hline Age (y) & -0.155 & 0.704 & 0.108 & 0.735 \\
\hline Sex & 0.461 & 0.436 & -0.006 & 0.135 \\
\hline
\end{tabular}

Abbreviation: CCT - central corneal thickness; $\mathrm{Cr}$ - radius of corneal curvature (mm), K - keratometry (D); SE - spherical equivalent; D - Diopter

fractive error $(p=0.191 / 0.615)$, age $(p=0.704 / 0.735)$ and sex $(p=0.436 / 0.135)$ and it was showen in Table 4 .

\section{DISCUSION}

The main purpose of this study was to determine central corneal thickness, corneal curvature and refractive error in patients with primary angle-closure glaucoma and compare the same data with patients with primary open-angle glaucoma. We found that CCT in PACG and POAG group were in normal range and there was no diference between them. In a meta-analysis of worldwide literature, the average CCT of normal eyes in various racial groups with ultrasound pachimetry was 544 $\mu \mathrm{m}$, similar to our study results: CCT - in PACG group was $549 \mu \mathrm{m}$ and in POAG group was $547 \mu \mathrm{m}$ [8]. Also, similar was found in study of Pang et al. [9] for eyes with PACG; mean CCT was $542 \mu \mathrm{m}$ but CCT in POAG group was thinner - $539 \mu \mathrm{m}$. Thinner corneas was also found on CCT study from Brasil; and there were no differences in the mean CCT of PACG $(531.1 \mu \mathrm{m})$, POAG $(520.6 \mu \mathrm{m})$ and normal eyes $(519.2 \mu \mathrm{m})(\mathrm{p}=0.18)$ [10].
The next purpose of our study was to determine correlation between CCT and other variables: CC, refractive error, sex and age. Our study showed that there was not statistically significant correlation between mean CCT and sex in both groups, as also no correlation with age. There is currently no consensus on how CCT varies among men and women. Some studies note that there no differences [9], another emphasis that female subjects have slightly thicker corneas than male subjects, whereas other found that males have slightly thicker corneas than females [11]. Previous reports on the association between CCT and age are contradictory: some studies have found no significant association [12], whereas others have found a statistically significant inverse relationship between CCT and age. On one side, Nemesure et al. [13] and Aghaian et al. [14] found a decrease the central corneal thickness with increasing age, however we did not see correlation between CCT and age, agreeing with Shimmyo et al. [12] and Rotterdam Study [15].

Studies that have attempted to investigate the effects of refractive errors on CCT have reported conflicting results. One reports showed no correlation between corneal thickness and level of myopia, whereas another study found the cornea to be thinner in more myopic 
eyes [16]. In our study, we did not found correlation between CCT and refractive error in both studied group.

Also, we wanted to reveal correlation between IOP and CCT, CC, refractive error, sex and age. Accurate IOP measurement is an important factor in the diagnosis and management of glaucoma, but various sources of error may affect the accuracy of measurements. Central corneal thickness is well known and affects IOP readings. The Ocular Hypertension Study recognized the significance of CCT on GAT. They found that eyes with thinner corneas had a higher risk of developing primary open angle glaucoma than eyes with thicker cornea [17]. In our study we showed positively correlation between CCT and IOP in group with POAG and in group with PACG there were no correlation between these two parameters.

Regarding corneal curvature, our results showed that eyes with PACG had flatter corneas than eyes with POAG. As many published studies suggest correction factors based on CCT and GAT, however the effects of CC on IOP measurements by GAT remains uncertain. Paranahos et al. [18] found no correlation between CC and IOP measurements by GAT and non contact tonomtery in study group of 404 eyes. Also, in our study, there was no association CC and IOP in both studied group. Contrary, in some of previous publication, there was association between corneal curvature and IOP reading obtained with GAT, like in Saleh et al. Study [19], there was a weak correlation between mean radius of CC and IOP measurements with GAT and ocular blood flow pneumatonometer [20]. Orssengo and associates [21] recently discussed errors in GAT by theroretical mathematical models. They discussed the deformation of central cornea flattened by pressure of the prism and bulging outward from the middle to peripheral cornea by the inner pressure of eye. They concluded that central corneal thickness, corneal curvature and area applanated should be considered in adjusting errors of GAT and alluded to the role of variations in Poisson rate of central tissue of different indivduals.

Our results also showed that eyes with PACG were hyperopic. A study dating back to 1970 stated that there is relations between PACG and hyperopia [22]. Since then, the most studies on PACG and refarctive error have been performed in Asian countries. The Beijing study [23] found a relation between hyperopia and anterior chambre angle, suggesting that hyperopia is a predominant risk factor for PACG. Saskia et al. [24] was the first study about risk factors of PACG in a European population and in their population most of PACG patients were hyperopic but they though that hyperopia may be involved in the pathogenesis of PACG, but it cannot be accounted as a risk factor.

In our study, in the multiple regression analysis, age and especially myopia were significantly associated with IOP in POAG group. It agrees with previous studies [25, 26] which confirmed that older age and myopia are important risk factor for primary open angle glaucoma.

Our study had a few limitations. Firstly, we did not have normal control group. Another potential weakness is the relatively small sample size. Earlier studies have showen that there are many factors which may be associated with CCT, including ocular factors such as axial lenth, anterior chamber depth, lens thickness and systemic factors such as presence of diabetes mellitus, body mass index, serum glucose levels. In this study, we did not include these factors for analysis. Sihota et al. [27] showed a difference in a mean CCT between acute PACG and chronic PACG, however, we were unable to obtain such data as all patients in this study had chronic PACG.

\section{CONCLUSION}

We found that CCT in PACG and POAG group were in normal range and there was no diference between them. Our results showed that the eyes with PACG had the flatter corneas than eyes with POAG and were hyperopic. Thickness and corneal curvature are two independent factors. Greater CCT was associated with higher intraocular pressure in group POAG.

\section{REFERENCES}

1. Quigley HA, Congdon NG, Friedman DG. Glaucoma in China (and worldwide): changes in established thinking will decrease preventable blindness. Br J Ophthalmol. 2001:1271-1272.

2. European Glaucoma Society. Terminology and guidelines for glaucoma, 4rd ed. Savona, Italy: Editrice DOGMA S.r.l.;2014. p100.

3. Bonomi L, Marchini G, Marraffa M et al. Epidemiology of angle-closure glaucoma: prevalence, clinical types and association with peripheral anterior chamber depth in Egna-neumarkt glaucoma study. Ophthalmology. 2000; 107(5):998-1003.

4. Nolan WP, Foster PJ, Devereux JG, Uranchimeg D, Johnson GJ, Baasanhu J. YAG laser iridotomy treatment for primary angle closure in in east Asian eyes. British Journal of Ophthalmology. 2000; 84(11):1255-1259.

5. Shih CY, Graff Zivin JS, Trokel SL, et al. Clinical significance of central corneal thickness in the managment of glaucoma. Arch Ophthlamol. 2004:1270-1275.

6. Miglior S, PfeifferN, Torri V, et al. Predictive factors for open- angle glaucomaamong patients with ocular hypertension in the European Glaucoma Prevention Study. Ophthalmology. 2007; 114:3-9.

7. Zhang $\mathrm{D}$, Shi $\mathrm{Y}$, Gong B et al. An association study of the COL1A1 gene ang high myopiain a Han Chinese population. Molecular Vision. 2011; 17:3379-3383. 
8. Doughty MJ, Zaman ML. Human corneal thickness and its impact on intraocular pressure measure: a review and metaanalysis approach. Surv Ophthalmol. 2000; 44:367-408.

9. Pang CE, Lee KY, Su DH, Htoon HM, Ng JY, Kumar RS, Aung T. Central corneal thickness in Chinese Subjects with Primary Angle Closure Glaucoma. J Glaucoma. 2011; 20:401-404.

10. Mello PR, Meirelles SH, Moraes Junior HV. Correlation between central corneal thickness and axial length in patients with glaucoma and normal eyes. Arq Bras Oftalmol. 2009; 72:497-502.

11. Xu L, Zhang H, Wang YX, Jonas JB. Central corneal thickness and glaucoma in adult Chinese: the Beijing Eye Study. J Glaucoma. 2008; 17(8):647-53.

12. Shimmyo M, Ross AJ, Moy A, et al. Intraocular pressure, Goldmann applanation tension, corneal thickness and corneal curvature in Caucasians, Asians, Hispanics and AfricanAmericans. Am J Ophthalmol. 2003; 136:603-613.

13. Nemesure B, Wu SY, Hermis A, et al. Corneal thickness and intraocular pressure in Barbados eye studies. Arch Ophthalmol. 2003; 121:240-244.

14. Aghaian E, Choe JE, Lin S, et al. Central corneal thickness of Caucasians, Chinese, Hispanics, Filipinos, African Americans, and Japanese in a Glaucoma Clinic. Ophthalmology. 2004; 111: 2211-2219.

15. Wolfs RC, Klaver CC, Fingerling JR, Grobee DE, HoffmanA, de Jong PT. Distribution of central corneal thickness and its association with intraocular pressure: Rotterdam Study. Am J Ophthalmol. 1997; 123:767-772.

16. Farm HB, How AC, Baskaran M, Lim KL, Chan YH, Aung T. Central corneal thickness and its relationship to myopia in Chinese adults. Br J Ophthalmol. 2006; 90:1451-1453.

17. Brandt JD, Beiser JA, Kass MA, Gordon MO. Central corneal thickness in the Ocular Hypertension Treatment Study(OHTS). Ophthamology. 2001; 108:1779-1788.

18. Paranhos A, Paranhos FR, Prata JA, et al. Infuence of keratometric readings on comparative intraocular pressure measurements with Goldmann,Tono-Pen, and non-contact tonometers. J Glaucoma. 2000; 9:219-223.

19. Saleh TA, Adams, McDermott B, Claridge K, Ewings $P$. Effects of central corneal thickness and corneal curvature on the intraocular pressure measurements by Goldmann applanation tonometer and ocular blood flow pneumatonometer. Clinical and Experimenatl Ophthalmology. 2006; 34:516-520.

20. Harada $\mathrm{Y}$, Hirose N, Kubota T, Tawara A. The influence of central corneal thickness and corneal curvature radius on the intraocular pressure as measured by different tonometers: noncontact and goldmann applanation tonometers. J Glaucoma. 2008; 17(8):619-25.

21. Orssengo GJ, Pye DC. Determinationof the true intraocular pressure and moduls of elasticity of the human cornea in vivo. Bull math Biol. 1999; 61:551-572.

22. Lowe RF. Aetiology of the anatomical basis for primary angleclosure glaucoma. Biometrical comparisons between normal eyes and eyes with primary angle-closure glaucoma. British Journal of Ophthalmology. 1970; 54(3):161-169.

23. Xu L, Cao WF, Wang YX, Chen CX, Jonas JB. Anterior chamber depth and chamber angle and their associations with ocular and general parameters. The Beijing Eye Study. American Journal of Ophthalmology. 2008; 145(5):929-936.

24. van Romunde SH, Thepass G, Lemij HG: Hyperopia an Important Risk Factor for PACG in the Dutch Population?-A Case Control Study. Journal of Ophthalmology. 2013; 2013:630481.

25. Leske MC, Wu SY, Hennis A, et al. Risk factors for incident open-angle glaucoma: the Barbados Eye Studies. Ophthalmology. 2008; 115(1):85-93.

26. Perera SA, Wong Ty, Tay WT, et al. Refractive error, axial dimensions and primary open-angle glaucomathe Sigapore Malay Eye study. Arch Ophthalmol. 2010; 128(7):900-5.

27. Sihota R, Gupta V, Agarwal HC, et al. Comparsion of symptomatic and asymptomatic chronic PACG, open angle glaucoma and controls. J Glaucoma. 2000; 9:208-213

\section{SRPSKI}

\section{CENTRALNA DEBLJINA ROŽNJAČE, ZAKRIVLJENOST ROŽNJAČE I REFRAKTIVNA GREŠKA KOD PACIJENATA SA PRIMARNIM GLAUKOMOM ZATVORENOG I OTVORENOG UGLA}

Marić V. ${ }^{1}$, Marković V. ${ }^{1,2}$, Božić M. ${ }^{1,2}$, Marjanović I. ${ }^{1,2}$

${ }^{1}$ Klinika za očne bolesti, Klinički Centar Srbije, Beograd, Srbija

${ }^{2}$ Univerzitet u Beogradu, Medicinski fakultet, Beograd, Srbija

\section{SAŽETAK}

Primarni glaukom zatvorenog ugla je znatno učestaliji u Azijiskim zemljama u odnosu na primarni glaukom otvorenog ugla koji je predominantan među Belom rasom te zbog toga postoji nedostatak podataka o centralnoj debljini i zakrivljenosti rožnjače kod primarnog glaukoma zatvorenog ugla u Evropi. Odrediti centralnu debljinu rožnjače, zakrivljenost rožnjače i refraktivnu grešku kod pacijenata sa primarnim glaukomom zatvorenog (PACG) i otvorenog ugla (POAG). U studiji je bilo uključeno 288 pacijenata, 132 
pacijenta sa primarnim glaukom zatvorenog ugla (prosečne starosti $73 \pm 7$ godina) $i 156$ pacijenata sa primarnim glaukomom otvorenog ugla (prosečne starosti $70 \pm 7$ godina). Podaci su prikupljeni od pacijanata sa PACG koji su upućeni za laser perifernu iridotomiju na Kliniku za očne bolesti u Beogradu u periodu od Januara 2012 do Oktobra 2012 godine i njihovih kontrola sa POAG koji su pregledani u istom periodu. Podaci dobijeni sa desnog oka uzeti su za analizu. Srednja debljina rožnjače u grupi PACG/POAG-a bila je $549 \pm 38 / 547 \pm 35 \mu \mathrm{m} \quad(p=0,353)$ i srednji radijus zakrivljenosti rožnjače $7,92 \pm 0,22 / 7,75 \pm 0,29 \mathrm{~mm} \quad(p=0,003)$. Nije postojala statistički značajna povezanost između IOP i srednjeg radijusa zakrivljenosti rožnjače u obe grupe PACG $(p=0,244) / P O A G ~ p=(0,637)$ dok je postojala u grupi POAG, sa refraktivnom greškom $(p=0,005)$ kao i sa srednjom debljinom rožnjače $u$ istoj grupi $(p<0,001)$. U našoj studiji nije postojala razlika u srednjoj debljini rožnjače između pacijanata sa primarnim glaukomom zatvorenog i otvorenog ugla. Oči sa angularnim glaukomom imale su ravniju rožnjaču i veću hipermetropnu refraktivnu grešku.

Ključne reči: centralna debljina rožnjače, zakrivljenost rožnjače, refraktivna greška, primarni glaukom zatvorenog ugla, primarni glaukom otvorenog ugla 